\section{A comparison between stomatal ozone uptake and AOT40 of deciduous trees in Japan}

\author{
Hoshika Y, Shimizu Y, Omasa K
}

\begin{abstract}
A comparison of the maps of stomatal ozone uptake $\left(\mathrm{AF}_{\mathrm{st}} \mathrm{O}\right)$ and concentrations exceeding $40 \mathrm{ppb}$ (AOT40) for dominant temperate deciduous tree species (Quercus serrata, Fagus crenata, Betula ermanii) was conducted in Japan. Estimations of stomatal ozone uptake were accomplished using estimated ozone concentration, climate data, and vegetation data. Key parameters such as stomatal conductance parameters for each species were collected from scientific literature in Japan. Stomatal closure induced by vapour pressure deficit affected the $\mathrm{AF}_{\mathrm{st}} \mathrm{O}$ values in warmer part of Japan. For this reason, the areas with high AOT40 did not always correspond to the areas with high $\mathrm{AF}_{\mathrm{st}} 0$. The result showed that ozone risk assessment using AOT40 is VPD-constrained in central Japan, which implies an overestimation of risk compared to $A F_{s t} 0$. While in Europe AOT40 is higher where water stress is recurrent, AOT40 peaked in the cool and humid climate region of central-eastern Japan where also stomatal ozone uptake reached maximum values.
\end{abstract}

Keywords: Deciduous forest trees, Ozone uptake modeling, Stomatal conductance, Japan, Ozone

\section{Introduction}

Phytotoxic nature of ozone has been well known for decades (e.g., Nies 1980, Nies 1984). Surface ozone concentrations are increasing in East Asia because of rapid increases in emissions of the main critical ozone precursors, Nitrogen oxides and volatile organic compounds (Naja \& Akimoto 2004). Ohara \& Sakata (2003) reported that the annual average concentration of photochemical oxidant, mainly ozone, increased with high rate $\left(0.33 \mathrm{ppb}\right.$ year $\left.^{-1}\right)$ from 1985 to 1999 in Japan. Therefore, assessments of ozone impacts on plants have become very significant in Japan.

In Japan, effects of ozone on the growth of forest tree species have been investigated by using AOT40, which represents the cumulative exposure above a hourly threshold con-

$\square$ Graduate School of Agricultural and Life Sciences, The University of Tokyo, 1-1-1 Yayoi, Bunkyo-ku, 113-8657 Tokio (Japan)

(a) Yasutomo Hoshika

(ahoshika@mail.ecc.u-tokyo.ac.jp)

Received: Feb 15, 2011 - Accepted: Mar 31, 2011

Citation: Hoshika Y, Shimizu Y, Omasa K, 2011. A comparison between stomatal ozone uptake and AOT40 of deciduous trees in Japan. iForest 4: 128-135 [online 2011-0601] URL: http://www.sisef.it/iforest/ show.php?id=573 centration of $40 \mathrm{ppb}$ during daylight hours (e.g., Izuta et al. 2001, Kohno et al. 2005). Kohno et al. (2005) suggested that 8-15 $\mathrm{ppm} \cdot \mathrm{h}$ AOT40 for sensitive species (e.g., Fagus crenata), and $15-30 \mathrm{ppm} \cdot \mathrm{h}$ AOT40 for moderately sensitive species (e.g., Quercus serrata) from April to September as critical level for forest species, are able to induce a $10 \%$ growth reduction. Critical levels for forest trees are set at $5 \mathrm{ppm} \cdot \mathrm{h}$ AOT40 corresponding to a $5 \%$ growth reduction in Europe (UNECE 2004). An assessment approach using AOT40 has the advantage of being simple because only atmospheric ozone concentration data are needed. However, ozone damage to plants depends not only on atmospheric ozone concentrations but also on stomatal ozone uptake into leaves. Several studies suggested that stomatal ozone uptake was closely related to ozone damages (e.g., Omasa et al. 2002, Paoletti \& Manning 2007). For this reason, a stomatal flux-based approach using stomatal ozone uptake is expected to provide better assessments of ozone damage to plants in Europe (Emberson et al. 2000). Critical levels for ozone risk using the stomatal fluxbased indices were set for potato and wheat, and provisionally for sensitive forest species (beech, birch - UNECE 2004). Karlsson et al. (2007) reported that the stomatal fluxbased indices were superior to AOT40 for ozone-sensitive species, based on a reanalysis of published ozone exposure-response data.
Very little has been done to develop the stomatal flux-based approach for assessing ozone damage to plants in Japan. The assessment approach using AOT40 was suggested to be appropriate for Japan because of much precipitation and limited water stress in $\mathrm{Ja}$ pan (Watanabe et al. 2010). However, this assumption has not been verified yet. In this study, we developed a model of cumulative stomatal ozone uptake $\left(\mathrm{AF}_{\mathrm{st}} \mathrm{O}\right)$ and assess the spatial distribution of $\mathrm{AF}_{\mathrm{st}} \mathrm{O}$ compared to AOT40 for deciduous forest tree species in Japan.

\section{Materials and methods}

\section{Vegetation data}

Deciduous forest tree species were classified into three forest types within two climatic zones (cool-temperate and warm-temperate zones) in Japan (Nakashizuka \& Iida 1995). Cool-temperate zone and warm-temperate zone are mainly in northern Japan and western Japan, respectively. Regarding the forest types, cool-temperate mixed broadleaf/conifer forest and cool-temperate deciduous forest are distributed in the cooltemperate zone. Cool-temperate deciduous forest is just in central-eastern Japan, with a humid climate throughout the year and heavy snow in winter. In the cool-temperate deciduous forest, beech (Fagus crenata) is the dominant species. The cool-temperate mixed forest is dominated by deciduous oak (e.g., Quercus crispula) and birch (Betula ermanii). In the warm-temperate zone, the forest type is classified as warm-temperate deciduous forest, and is dominated by deciduous oak (e.g., Quercus serrata). Three dominant species (Quercus serrata; Fagus crenata; Betula ermanii) were selected for comparison between $\mathrm{AF}_{\mathrm{st}} \mathrm{O}$ and AOT40. The distributions of the species targeted by this study are shown in Fig. 1. A distribution was determined based on the vegetation data of the National Survey on the Natural Environment, investigated by the Ministry of the Environment (http://www.biodic.go.jp/J-IBIS. $\mathrm{html})$. Spatial resolution of these data was 1 $\times 1 \mathrm{~km}$.

\section{Input data}

Climate data (air temperature, air humidity, solar radiation and wind speed) and ozone concentration data for the year 2000 (Takigawa et al. 2007) were input into our model. These data were estimated using CHASER (Sudo et al. 2002) and the WRF/Chem model (Grell et al. 2005) provided at $6 \mathrm{~h}$ temporal resolution, a spatial resolution of $40 \times 40 \mathrm{~km}$ across Japan. We used these data as input data near ground surface at $20 \mathrm{~m}$ high. Validation for the model estimates of ozone concentration was conducted at several monitoring sites in Ja- 
$120^{\circ} \mathrm{E}$
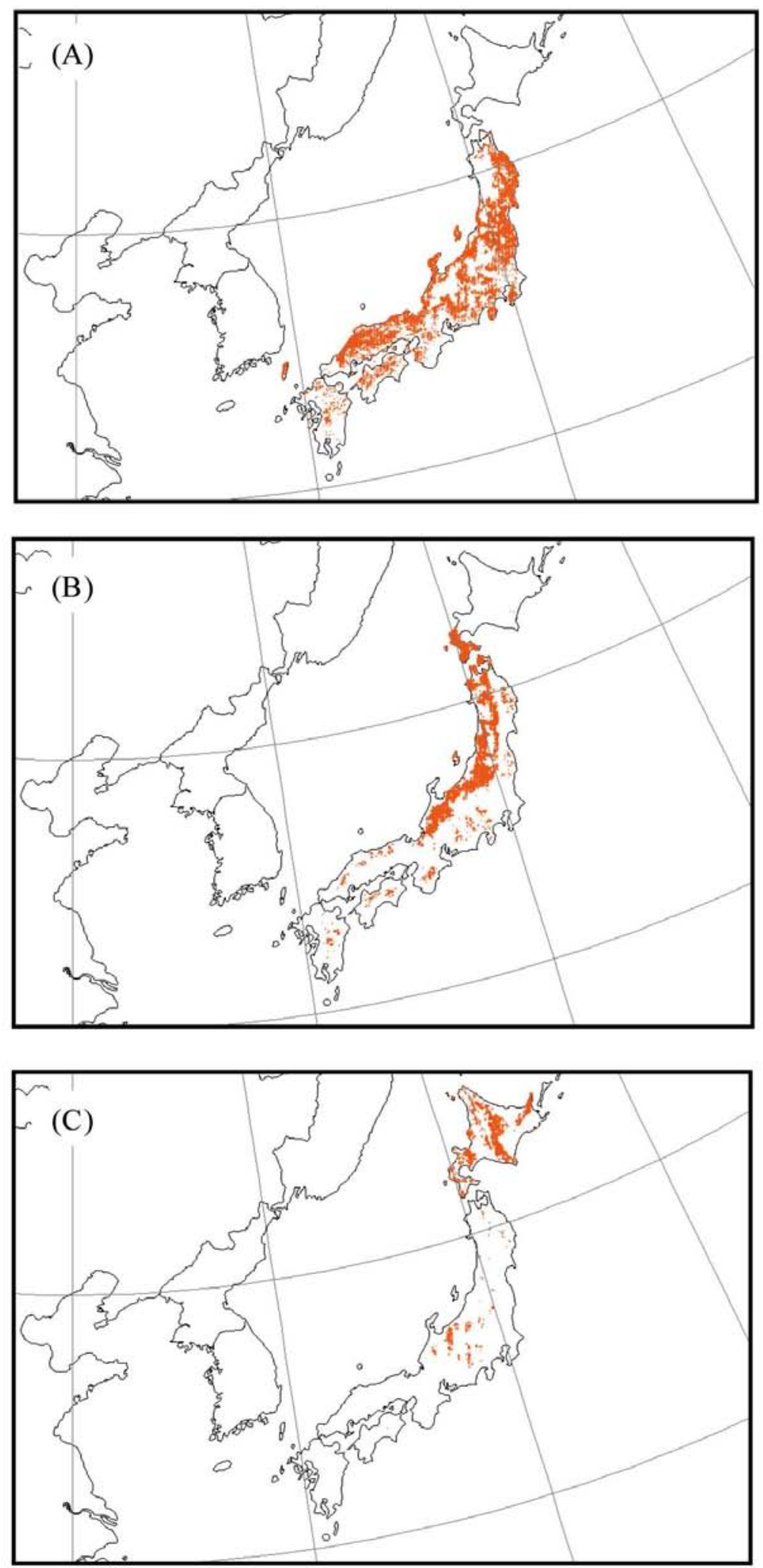

Fig. 1 - Distribution of dominant forest species in Japan (A: Quercus serrata; B: Fagus crenata; C: Betula ermanii). $40^{\circ} \mathrm{N}$

$30^{\circ} \mathrm{N}$

pan (Takigawa et al. 2007). Although further validation and model improvement may be needed, the model estimates were used for estimation of stomatal ozone uptake.

Input data of distributions for deciduous tree species were derived from identifying whether the grid space $(40 \times 40 \mathrm{~km})$ included the distribution of vegetation data shown in Fig. 1 or not. The estimation of stomatal ozone uptake was conducted in each grid square $(40 \times 40 \mathrm{~km})$ with $6 \mathrm{~h}$ time steps.

\section{Estimation of AOT40}

AOT40 was estimated using ozone concentration at the top of the canopy as recommended for ozone risk assessment (UNECE 2004). We used ozone concentration data at $20 \mathrm{~m}$ high as $\mathrm{C}\left(\mathrm{z}_{1}\right)$. AOT40 was calculated as follows (eqn. 1):

$$
A O T 40=\int_{i=1}^{n} \max \left(C\left(z_{1}\right)_{i}-40.0\right) \cdot d t
$$

$40^{\circ} \mathrm{N}$

where $\mathrm{C}\left(\mathrm{z}_{1}\right)_{\mathrm{i}}$ is averaged ozone concentration for 6 hours at the top of the canopy $(\mathrm{ppb}), \mathrm{n}$ is the number of data for ozone concentrations. AOT40 was calculated over daylight hours with a solar irradiation higher than $50 \mathrm{~W} \mathrm{~m}^{-2}$ from April to September (e.g., Kohno et al. 2005).

\section{Stomatal conductance model}

Leaf-level stomatal conductance of water vapor $\left(g_{s w}\right)$ was estimated using the multiplicative model (Jarvis 1976, Emberson et al. 2000 - eqn. 2):

$g_{S W}=g_{\text {max }} \cdot f_{\text {phen }} \cdot f_{\text {light }} \cdot \max \left\{f_{\text {min }},\left(f_{\text {temp }} \cdot f_{V P D} \cdot f_{\text {SMD }}\right)\right\}$

where $g_{\max }$ is the maximum stomatal conductance. The other functions are limiting factors of $g_{\max }$ and are scaled from 0 to $1 . f_{\min }$ is the minimum stomatal conductance and is set to 0 in this study because we could not get data of $g_{\min }$ from the literatures. $f_{\text {phen }}$ is the variation in stomatal conductance with leaf age, and $f_{\text {light }}, f_{\text {temp }}, f_{\mathrm{VPD}}$, and $f_{\mathrm{SMD}}$ are functions of photosynthetically photon flux density at the leaf surface (PPFD, $\mu \mathrm{mol}$ photons $\mathrm{m}^{-2} \mathrm{~s}$ $\left.{ }^{1}\right)$, temperature $\left(\mathrm{T},{ }^{\circ} \mathrm{C}\right)$, vapor pressure deficit (VPD, $\mathrm{kPa}$ ), and volumetric soil water content $\left(\theta, \mathrm{m}^{3} \mathrm{~m}^{-3}\right)$, respectively.

The variation in stomatal conductance with leaf age $\left(f_{\text {phen }}\right)$ modifies $g_{\max }$ as a function of time within the leaf duration (Emberson et al. 2000). Maruyama \& Honda (1993) reported that it took about 1 month for $g_{\text {sw }}$ to reach its peak from leaf onset, and to decline due to its senescence until leaf fall for Japanese beech and deciduous oak species. Therefore, we assumed that $f_{\text {phen }}$ increased linearly from 0 to 1 during the first 30 days after leaf onset and decreased linearly from 1 to 0 during the 30 days prior to leaf fall.

The functions $\left(f_{\text {light }}, f_{\text {temp }}\right.$ and $\left.f_{\mathrm{VPD}}\right)$ have been expressed in various forms (e.g., Jarvis 1976, 
Tab. 1 - Parameters of the stomatal conductance model for each dominant deciduous tree species in Japan.

\begin{tabular}{|c|c|c|c|c|c|c|}
\hline \multirow{2}{*}{ Parameter } & \multicolumn{2}{|r|}{$\begin{array}{l}\text { Deciduous oak } \\
\text { (Q. serrata) }\end{array}$} & \multicolumn{2}{|r|}{$\begin{array}{c}\text { Beech } \\
(\text { F. crenata })\end{array}$} & \multicolumn{2}{|r|}{$\begin{array}{c}\text { Birch } \\
\text { (B. ermanii) }\end{array}$} \\
\hline & Value & References & Value & References & Value & References \\
\hline 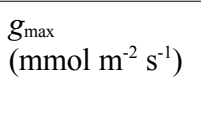 & 480 & $\begin{array}{l}\text { Tanaka et al. (1998), } \\
\text { Sirisampan et al. (2003), } \\
\text { Yamazaki et al. (2006) }\end{array}$ & 425 & Iio et al. (2004) & 680 & $\begin{array}{l}\text { Muraoka \& Koizumi (2005), } \\
\text { Yamazaki et al. (2006) }\end{array}$ \\
\hline $\begin{array}{l}f_{\text {light } 0.5} \\
\left(\mu \mathrm{mol} \mathrm{m} \mathrm{m}^{-2} \mathrm{~s}^{-1}\right)\end{array}$ & 145 & $\begin{array}{l}\text { Tanaka et al. (1998), } \\
\text { Sirisampan et al. (2003) }\end{array}$ & 90 & Iio et al. (2004) & 110 & Yamazaki et al. (2006) \\
\hline$T_{\text {opt }}\left({ }^{\circ} \mathrm{C}\right)$ & 24 & Tanaka et al. (1998), & 25 & Iio et al. (2004) & 25 & Yamazaki et al. (2006) \\
\hline$T_{\min }\left({ }^{\circ} \mathrm{C}\right)$ & 0 & Yamazaki et al. (2006) & 0 & & 0 & \\
\hline$T_{\max }\left({ }^{\circ} \mathrm{C}\right)$ & 48 & & 40 & & 45 & \\
\hline$F_{\mathrm{VPD} \_.5}(\mathrm{kPa})$ & 2.1 & Yamazaki et al. (2006) & 2.4 & Iio et al. (2004) & 1.2 & Yamazaki et al. (2006) \\
\hline$a$ & 3.4 & & 1.9 & & 2.5 & \\
\hline
\end{tabular}
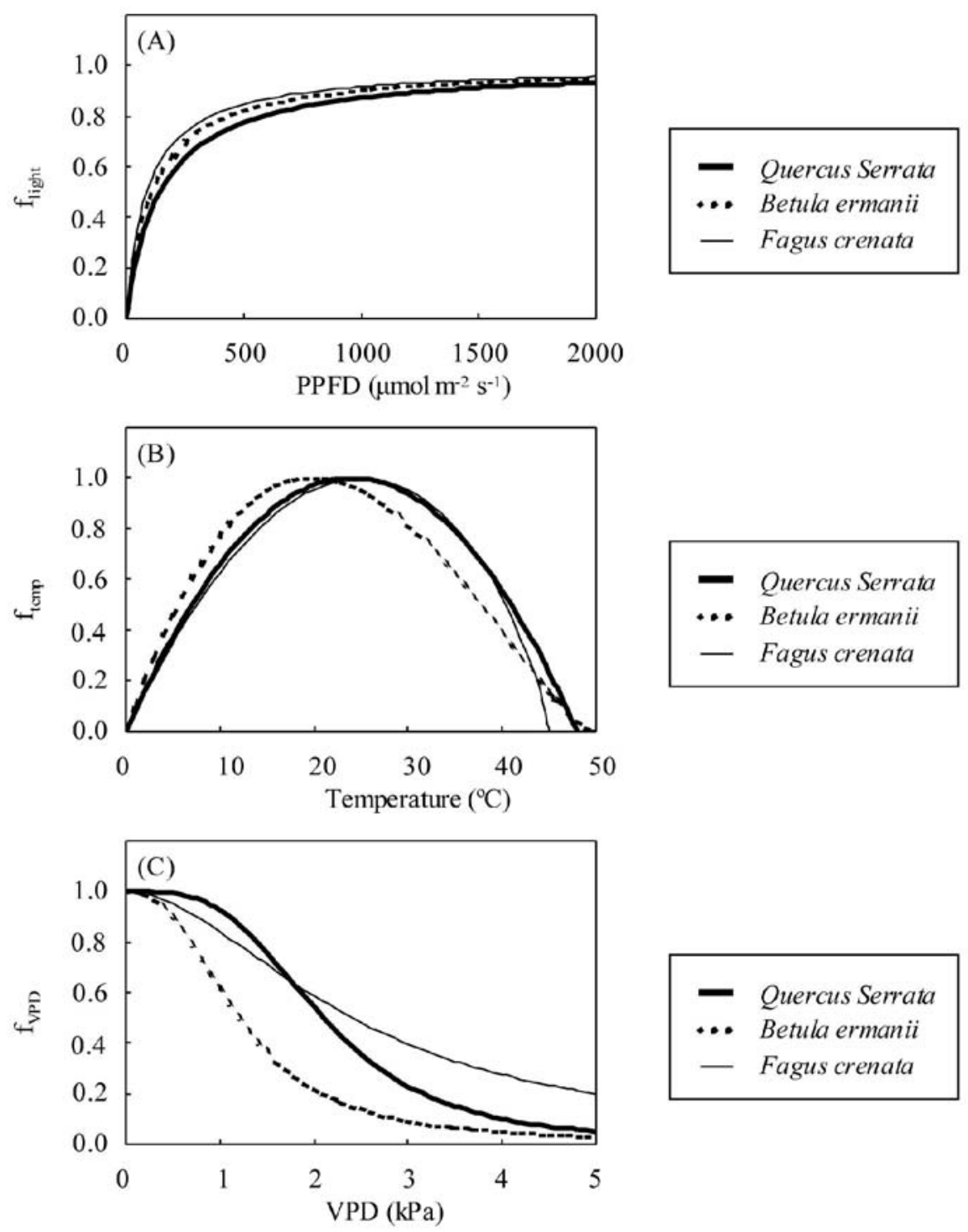

Fig. 2 - Plots of the functions $f_{\text {light }}(\mathrm{A}) ; f_{\text {temp }}(\mathrm{B}) ; f_{\mathrm{VPD}}(\mathrm{C})$ of the stomatal conductance model for three deciduous tree species. $f_{\text {light }}, f_{\text {temp }}$ and $f_{\mathrm{VPD}}$ are functions of photosynthetically photon flux density at the leaf surface (PPFD, $\mu \mathrm{mol}$ photons $\left.\mathrm{m}^{-2} \mathrm{~s}^{-1}\right)$, temperature $\left(\mathrm{T},{ }^{\circ} \mathrm{C}\right)$, and vapor pressure deficit $(\mathrm{VPD}, \mathrm{kPa})$, respectively.
Sirisampan et al. 2003, Emberson et al. 2000). In this study, the following formulas were selected because they have been frequently used in modeling studies in Japan (e.g., Sirisampan et al. 2003). These functions are expressed as follows (eqn. 3, eqn. 4, eqn. 5):

$$
\begin{gathered}
f_{\text {light }}=\frac{P P F D}{\left(P P F D+f_{\text {light }_{0.5}}\right)} \\
f_{\text {temp }}=\frac{T-T_{\min }}{T_{\text {opt }}-T_{\min }} \cdot\left(\frac{T_{\max }-T}{T_{\max }-T_{\text {opt }}}\right)\left(\frac{T_{\text {max }}-T_{\text {opt }}}{T_{\text {opt }}-T_{\text {min }}}\right) \\
f_{V P D}=\left[1+\left(\frac{V P D}{f_{V P D_{0.5}}}\right)^{a}\right]^{-1}
\end{gathered}
$$

where $f_{\text {light } 0.5}$ is the value of PPFD when $f_{\text {light }}$ $=0.5$, and $T_{\mathrm{opt}}, T_{\min }$, and $T_{\max }$ represent the optimum, minimum, and maximum temperatures for stomatal conductance, respectively. $f_{\mathrm{VPD}} 0.5$ is the value of VPD when $f_{\mathrm{VPD}}$ $=0.5$, and $a$ is a constant .

Tab. 1 lists the parameters used in the stomatal conductance model. Parameters for $f_{\text {light }}, f_{\text {temp }}, f_{\mathrm{VPD}}$, and $g_{\max }$ were determined from a review of scientific literature on stomatal conductance of temperate deciduous forest tree species in Japan: Quercus serrata (Tanaka et al. 1998, Sirisampan et al. 2003, Yamazaki et al. 2006), Fagus crenata (Iio et al. 2004), Betula ermanii (Muraoka \& Koizumi 2005, Yamazaki et al. 2006). Fig. 2 shows a plot of these functions in the stomatal conductance model.

Parameters of $f_{\text {SMD }}$ could not be included in the model because of insufficient published data about $f_{\text {SMD }}$ for temperate deciduous tree species in Japan. The $f_{\text {SMD }}$ values were not calculated in this study $\left(f_{\mathrm{SMD}}=1\right)$, although this assumption may lead to an overestimation of stomatal ozone uptake. However, Sirisampan et al. (2003) reported that the soil water content had no effect on the stomatal conductance for six tree species in central 
Japan. Therefore, the results would still allow a comparison of the maps between stomatal ozone uptake and AOT40.

Estimation of stomatal ozone uptake

Estimation of stomatal ozone uptake ( $F_{\text {st }}$; $\left.\mathrm{nmol} \mathrm{O} \mathrm{m}^{-2} \mathrm{~s}^{-1}\right)$ were calculated based on the assumption that the ozone concentration at the top of the canopy $\left[\mathrm{C}\left(\mathrm{z}_{1}\right)\right]$ represented a concentration near sunlit leaves at the top of the canopy (Emberson et al. 2007). Then stomatal ozone uptake was calculated as follows (eqn. 6):

$$
F_{s t}=C\left(z_{i}\right) \cdot \frac{1}{\left(r_{b}+r_{c}\right)} \cdot \frac{\left(g_{S W} / 1.65\right)}{\left(g_{S W} / 1.65+g_{\text {ext }}\right)}
$$

where $r_{\mathrm{b}}$ is the leaf boundary layer resistance $\left(\mathrm{s} \mathrm{m}^{-1}\right), r_{\mathrm{c}}$ is the leaf surface resistance $[=1 /$ $\left.\left(g_{\mathrm{sw}} / 1.65+g_{\mathrm{ext}}\right) ; \mathrm{s} \mathrm{m}^{-1}\right], 1.65$ accounts for the difference in diffusivity of water in air compared with ozone, and $g_{\text {ext }}$ is the external leaf or cuticular conductance $\left(\mathrm{s} \mathrm{m}^{-1}\right) \cdot g_{\text {ext }}$ was set to $0.0004 \mathrm{~s} \mathrm{~m}^{-1}$ (Emberson et al. 2007).

Leaf boundary layer resistance $\left(r_{\mathrm{b}}\right)$ was calculated from the wind speed at canopy height, $u\left(z_{1}\right)$ in $\mathrm{m} \mathrm{s}^{-1}$, and the mean leaf width, $L_{\mathrm{d}}$ (m, UNECE 2004 - eqn. 7):

$$
r_{b}=1.3 \cdot 150 \cdot\left(\frac{L_{d}}{u\left(z_{1}\right)}\right)^{0.5}
$$

where the factor 1.3 accounts for differences in diffusivity between heat and ozone. $L_{\mathrm{d}}$ for oak and beech/birch were determined as 0.1 and $0.05 \mathrm{~m}$, respectively, from leaf shape data in Japan (Endo 1940).

In Europe, the accumulative stomatal ozone uptake $\left(A F_{\text {st }} Y\right)$ was recommended to assess the ozone risk for forest species (Karlsson et al. 2007). It is given by the following equation (eqn. 8):

$$
A F_{s t} Y=\int \max \left(F_{s t}-Y, 0\right) \cdot d t
$$

where $Y$ is a threshold of stomatal ozone uptake $\left(\mathrm{nmol} \mathrm{O} \mathrm{O}^{-2} \mathrm{~s}^{-1}\right)$. In Europe, a threshold $Y$ is currently used (Emberson et al. 2007, Karlsson et al. 2007). However, it is not clear whether the same threshold of $F_{\text {st }}$ can be applied in Japan. Therefore, we did not set a threshold for the $F_{\text {st }}$ value $\left(\mathrm{AF}_{\mathrm{st}} 0\right)$ in the present study.

\section{Estimation of leaf duration}

Leaf duration was simply assumed based on phenological data in Japan (Tab. 2). We chose the data by including several species in Japan. Because we could not collect enough phenological data for each species, we assumed no difference in leaf duration among species. From these data, a leaf onset time was set depending on the latitude in Japan (leaf onset time $=3.4 \cdot$ latitude -9.1 ; $\mathrm{r}^{2}=0.89$ ). In contrast, time of leaf fall did not show a linear relationship with latitude.

\begin{tabular}{|c|c|c|c|}
\hline \multirow[b]{2}{*}{ Region } & \multicolumn{2}{|c|}{ Observation (day of year) } & \multirow[b]{2}{*}{ References } \\
\hline & $\begin{array}{c}\text { Leaf } \\
\text { onset }\end{array}$ & $\begin{array}{c}\text { Leaf } \\
\text { fall }\end{array}$ & \\
\hline $\begin{array}{l}\text { Western Japan } \\
\left(35^{\circ} 10^{\prime} \mathrm{N} 132^{\circ} 40^{\prime} \mathrm{E}\right)\end{array}$ & 107 & 339 & Ozaki et al. (2000) \\
\hline $\begin{array}{l}\text { Central-eastern Japan } \\
\left(34^{\circ} 55^{\prime} \mathrm{N} 137^{\circ} 45^{\prime} \mathrm{E}\right)\end{array}$ & 109 & 319 & Fujimoto (2008) \\
\hline $\begin{array}{l}\text { Central-eastern Japan } \\
\left(36^{\circ} 30^{\prime} \text { N } 138^{\circ} 20^{\prime} \mathrm{E}\right)\end{array}$ & 121 & 297 & Kato \& Hayashi (2008) \\
\hline $\begin{array}{l}\text { Northern Japan } \\
\left(39^{\circ} 90^{\prime} \mathrm{N} 141^{\circ} 00^{\prime} \mathrm{E}\right)\end{array}$ & 131 & 298 & Aoki \& Hashimoto (1995) \\
\hline $\begin{array}{l}\text { Hokkaido } \\
\left(42^{\circ} 59^{\prime} \mathrm{N} 141^{\circ} 23^{\prime} \mathrm{E}\right)\end{array}$ & 135 & 304 & Nakai et al. 2003 \\
\hline
\end{tabular}

Tab. 2 - Observed time (day of year) of leaf onset and leaf fall for deciduous forest trees in Japan.

Tab. 3 - Mean values ( \pm SD) of estimated AOT40 and $\mathrm{AF}_{\mathrm{st}} 0$ for deciduous tree species in each region of Japan. The values were calculated for each region including more than 5

\begin{tabular}{|c|c|c|c|c|}
\hline \multirow[b]{2}{*}{ Region } & \multirow{2}{*}{$\begin{array}{l}\text { AOT40 } \\
(\mathrm{ppm} \cdot \mathrm{h})\end{array}$} & \multicolumn{3}{|c|}{$\mathrm{AF}_{\mathrm{st}} \mathbf{0}\left(\mathrm{mmol} \mathrm{m}^{-2}\right)$} \\
\hline & & $\begin{array}{l}\text { Quercus } \\
\text { serrata }\end{array}$ & $\begin{array}{l}\text { Fagus } \\
\text { crenata }\end{array}$ & $\begin{array}{c}\text { Betula } \\
\text { ermanii }\end{array}$ \\
\hline $\begin{array}{l}\text { Hokkaido } \\
\left(42^{\circ}-44^{\circ} \mathrm{N} 140^{\circ}-145^{\circ} \mathrm{E}\right)\end{array}$ & $\begin{array}{l}5.1 \pm 1.6 \mathrm{a} \\
\quad(41)\end{array}$ & - & $\begin{array}{l}26.7 \pm 1.6 \mathrm{a} \\
(6)\end{array}$ & $\begin{array}{l}31.9 \pm 2.3 \mathrm{a} \\
(35)\end{array}$ \\
\hline $\begin{array}{l}\text { Eastern Japan } \\
\left(35^{\circ}-42^{\circ} \mathrm{N} 139^{\circ}-142^{\circ} \mathrm{E}\right)\end{array}$ & $\begin{array}{l}16.7 \pm 5.0 \mathrm{~b} \\
(53)\end{array}$ & $\begin{array}{c}35.9 \pm 3.4 \mathrm{a} \\
(44)\end{array}$ & $\begin{array}{l}35.1 \pm 3.2 b \\
(43)\end{array}$ & $\begin{array}{l}40.8 \pm 4.4 \mathrm{~b} \\
\quad(14)\end{array}$ \\
\hline $\begin{array}{l}\text { Central-eastern Japan } \\
\left(34^{\circ}-38^{\circ} \mathrm{N} 136^{\circ}-139^{\circ} \mathrm{E}\right)\end{array}$ & $\begin{array}{c}28.0 \pm 5.6 \mathrm{c} \\
(41)\end{array}$ & $\begin{array}{c}41.2 \pm 3.7 \mathrm{~b} \\
(41)\end{array}$ & $\begin{array}{c}41.1 \pm 2.7 \mathrm{c} \\
(32)\end{array}$ & $\begin{array}{l}48.3 \pm 4.0 \mathrm{c} \\
\quad(21)\end{array}$ \\
\hline $\begin{array}{l}\text { Central Japan } \\
\left(33^{\circ}-36^{\circ} \mathrm{N} 133^{\circ}-136^{\circ} \mathrm{E}\right)\end{array}$ & $\begin{array}{l}30.8 \pm 3.5 \mathrm{~d} \\
(31)\end{array}$ & $\begin{array}{c}36.0 \pm 3.5 \mathrm{a} \\
(30)\end{array}$ & $\begin{array}{c}40.1 \pm 2.1 \mathrm{c} \\
(17)\end{array}$ & - \\
\hline $\begin{array}{l}\text { Western Japan } \\
\left(31^{\circ}-35^{\circ} \mathrm{N} 130^{\circ}-133^{\circ} \mathrm{E}\right)\end{array}$ & $\begin{array}{c}26.4 \pm 4.3 \mathrm{c} \\
(40)\end{array}$ & $\begin{array}{c}40.6 \pm 2.3 \mathrm{~b} \\
(30)\end{array}$ & $\begin{array}{c}41.8 \pm 2.2 \mathrm{c} \\
(19)\end{array}$ & - \\
\hline \multicolumn{5}{|c|}{ Significance of difference } \\
\hline Kruskal-Wallis test & $<0.001$ & $<0.001$ & $<0.001$ & $<0.001$ \\
\hline
\end{tabular}
grids. Within the same parameter, values with different letters are significantly different (Kruskal-Wallis test, $\mathrm{p}<0.05$ - number of $40 \times 40 \mathrm{~km}$ grids, $\mathrm{p}<0.05$ ). $120^{\circ} \mathrm{E} \quad 130^{\circ} \mathrm{E} \quad 140^{\circ} \mathrm{E} \quad 150^{\circ} \mathrm{E}$

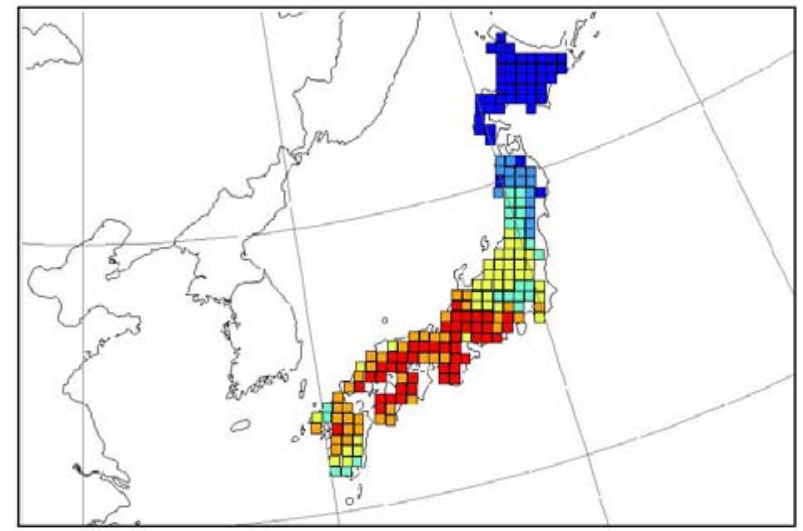

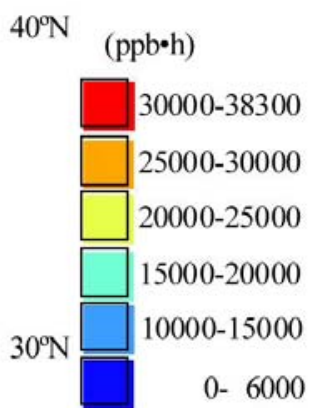

Fig. 3 - A map of estimated AOT40 values from April to September in Japan along the $40 \times$ $40 \mathrm{~km}$ grid of the CHASER and WRF/Chem models used to estimate climate and ozone input data. 
$120^{\circ} \mathrm{E} \quad 130^{\circ} \mathrm{E} \quad 140^{\circ} \mathrm{E} \quad 150^{\circ} \mathrm{E}$

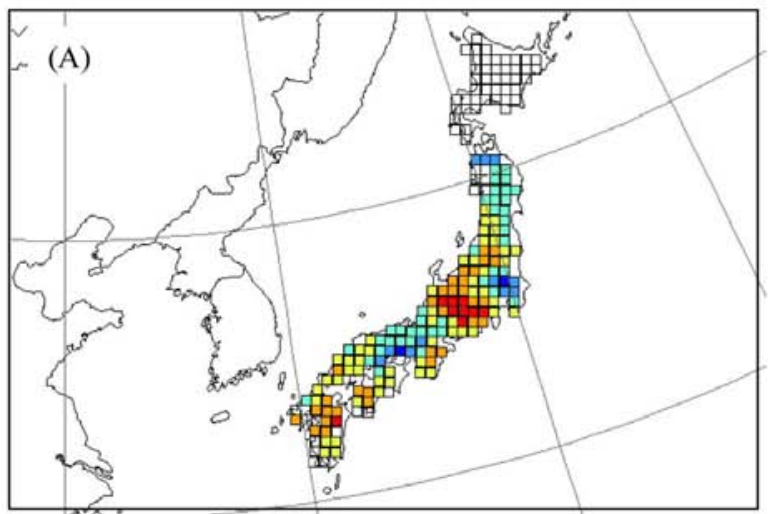

$40^{\circ} \mathrm{N}\left(\mathrm{mmol} \mathrm{m}^{-2}\right)$

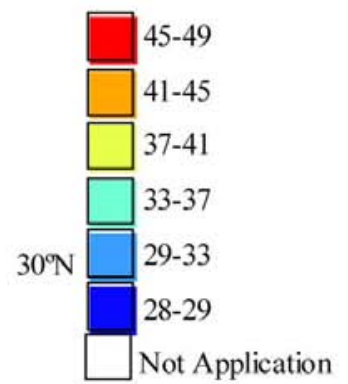

$120^{\circ} \mathrm{E}$

$130^{\circ} \mathrm{E}$

$140^{\circ} \mathrm{E}$

$150^{\circ} \mathrm{E}$

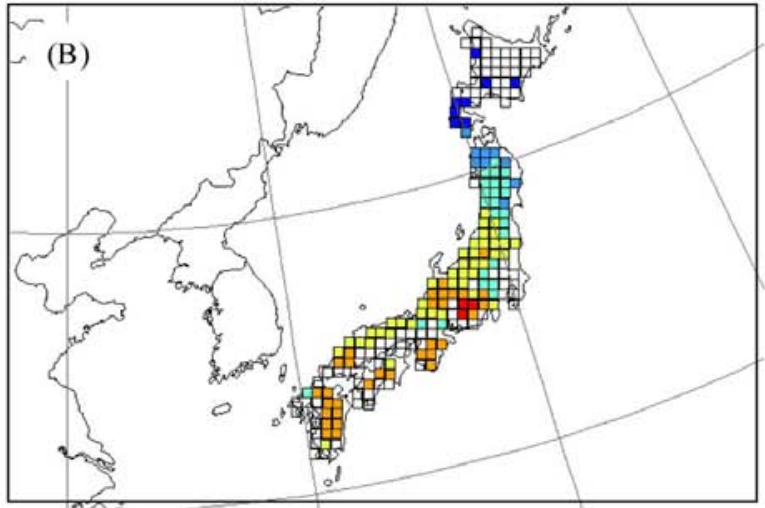

$40^{\circ} \mathrm{N}$

$\left(\mathrm{mmol} \mathrm{m} \mathrm{m}^{-2}\right)$

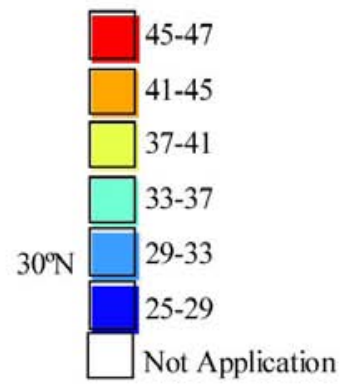

$120^{\circ} \mathrm{E}$

$130^{\circ} \mathrm{E}$

$140^{\circ} \mathrm{E}$

$150^{\circ} \mathrm{E}$
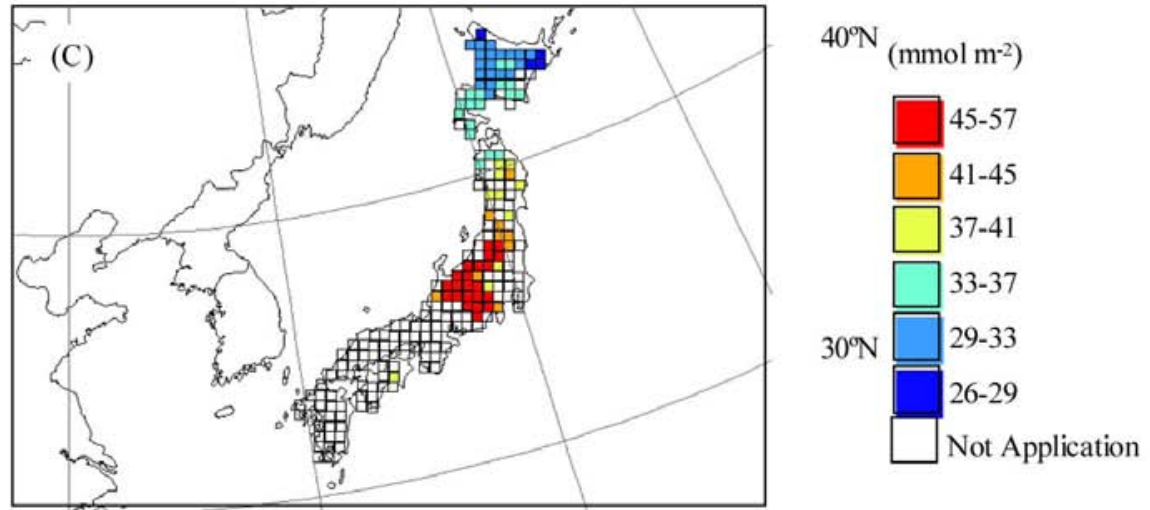

Fig. 4 - Maps of estimated $\mathrm{AF}_{\mathrm{st}} 0$ (accumulated stomatal ozone uptake) values of the deciduous tree species in Japan. (A): Quercus serrata; (B): Fagus crenata; (C): Betula ermanii.

Therefore, the averaged value of the time $(\mathrm{DOY}=311$, s.d. $=17)$ was adopted as time of leaf fall in this study.

\section{Statistics and data analysis}

To compare AOT40 and $\mathrm{AF}_{\mathrm{st}} \mathrm{O}$, maps of both indices were provided. In addition, averaged $\mathrm{AOT} 40$ and $\mathrm{AF}_{\mathrm{st}} \mathrm{O}$ were calculated for each region. The linear correlations between both indices, and between $f_{\mathrm{VPD}}$ in summer and $\mathrm{AF}_{\mathrm{st}} \mathrm{O}$ were tested. Moreover, difference of the indices among regions was tested with a Kruskal-Wallis test. Results were considered significant at $p<0.05$. Statistical analysis was performed with SPSS software version 11.5 (SPSS, Chicago, USA).

\section{Results}

Fig. 3 shows a map of the AOT40 values from April to September in Japan, and Tab.
3 shows an averaged value of AOT40 and $\mathrm{AF}_{\mathrm{st}} \mathrm{O}$ of each region in Japan. There were differences in the AOT40 values among regions. The AOT40 values showed the highest value more than $30 \mathrm{ppm} \cdot \mathrm{h}$ from central-eastern Japan $\left(34^{\circ}-38^{\circ} \mathrm{N} \quad 136^{\circ}\right.$ $\left.139^{\circ} \mathrm{E}\right)$ to western Japan $\left(31^{\circ}-35^{\circ} \mathrm{N} 130^{\circ}\right.$ $133^{\circ} \mathrm{E}$ - Fig. 3). In contrast, the AOT40 values were relatively low $(0-10 \mathrm{ppm} \cdot \mathrm{h})$ in Hokkaido $\left(42^{\circ}-44^{\circ} \mathrm{N} 140^{\circ}-145^{\circ} \mathrm{E}\right)$.

Fig. 4 (A-C) shows maps of the $\mathrm{AF}_{\mathrm{st}} 0$ values of the deciduous tree species in Japan. For Quercus serrata, $\mathrm{AF}_{\mathrm{st}} 0$ showed the highest value in central-eastern Japan (Fig. $4 \mathrm{~A})$. The averaged $\mathrm{AF}_{\mathrm{st}} \mathrm{O}$ values in this region were $41.2 \mathrm{mmol} \mathrm{m}^{-2} \mathrm{~s}^{-1}$ (Tab. 3). In this area, the $\mathrm{AF}_{\mathrm{st}} \mathrm{O}$ values reached about 50 mmol m$~^{-2}$ for Quercus serrata and Fagus crenata, and $55 \mathrm{mmol} \mathrm{m}^{-2}$ for Betula ermanii. In Hokkaido or eastern Japan $\left(35^{\circ}\right.$ $42^{\circ} \mathrm{N} 139^{\circ}-142^{\circ} \mathrm{E}$ ), the $\mathrm{AF}_{\mathrm{st}} \mathrm{O}$ values were lower than in central-eastern Japan (Fig. 4, Tab. 3). In Hokkaido, the averaged $\mathrm{AF}_{\mathrm{st}} \mathrm{O}$ values were $26.7 \mathrm{mmol} \mathrm{m}^{-2}$ and $31.9 \mathrm{mmol}$ $\mathrm{m}^{-2}$ for Fagus crenata and Betula ermanii, respectively (Tab. 3). The averaged $\mathrm{AF}_{\mathrm{st}} \mathrm{O}$ values for Quercus serrata were $35.9 \mathrm{mmol}$ $\mathrm{m}^{-2}$ in eastern Japan (Tab. 3). In central Japan $\left(33^{\circ}-36^{\circ} \mathrm{N} 133^{\circ}-136^{\circ} \mathrm{E}\right)$, the $\mathrm{AF}_{\mathrm{st}} 0$ values were similar to the levels in eastern Japan for Quercus serrata (Fig. 4A), Tab. 3). The

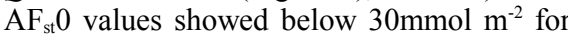
Quercus serrata in this region (Fig. 4A).

A comparison between the AOT40 and AF. ${ }_{\text {st }} 0$ maps (Fig. 3, Fig. 4) suggested a difference in the spatial pattern. Although the AOT40 values were different between eastern Japan, and central Japan, the $\mathrm{AF}_{\mathrm{st}} \mathrm{O}$ values were not significantly different for Quercus serrata (Tab. 3). These areas are the warmer parts of Japan. Fig. 5 shows the averaged $f_{\mathrm{VPD}}$ values for Quercus serrata in summer (July-August). In central Japan, the averaged $f_{\mathrm{VPD}}$ values were about 0.8 in the summer (Fig. 5) because of high temperature. The lower $f_{\mathrm{VPD}}$ values corresponded with the lower $\mathrm{AF}_{\mathrm{st}} \mathrm{O}$ areas for Quercus serrata.

For further analysis, we conducted a correlation analysis between both indices in Japan (Tab. 4). The result shows that the correlation between AOT40 and $\mathrm{AF}_{\mathrm{st}} \mathrm{O}$ was lower for Quercus serrata compared to other two species. Quercus serrata is mainly distributed in warm-temperate climate region (Fig. 1). Especially, the correlation was not significant in warmer part of Japan such as central and western Japan (Tab. 4). This result was influenced by effects of VPD on stomatal conductance (Fig. 5, Tab. 5).

For the other two species distributed in humid and cool region and high mountainous area, the correlation between AOT40 and AF ${ }_{\text {st }} 0$ was very high (Tab. 4). Fagus crenata is also distributed in the warmer part of Japan such as central and western Japan (Fig. 1). In 

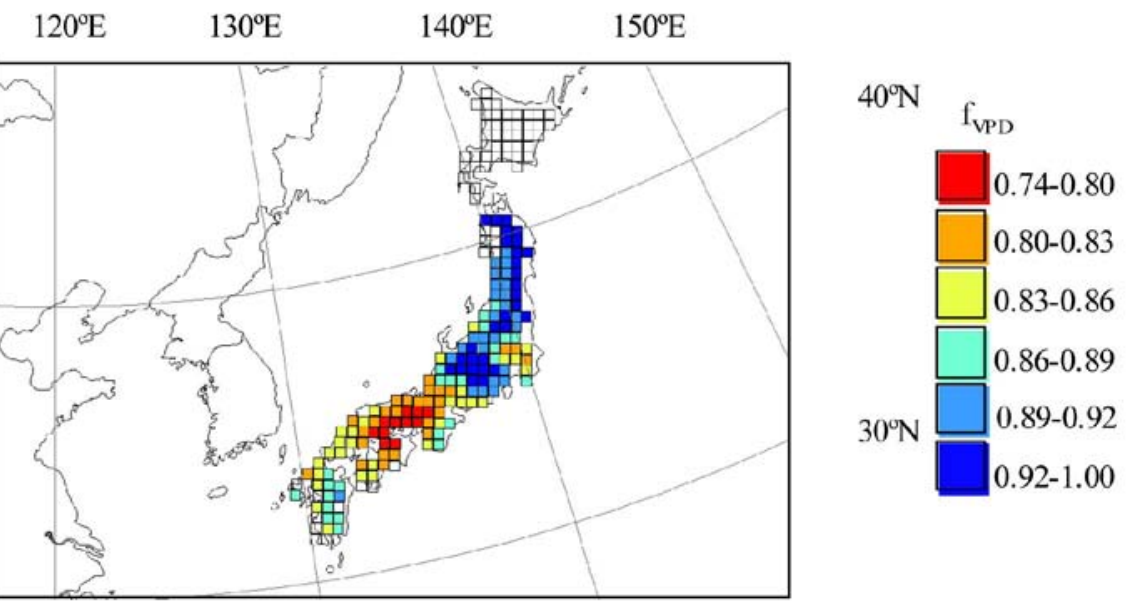

Fig. 5 - Spatial distribution of averaged $\mathrm{f}_{\mathrm{VPD}}$ values for Quercus serrata from July to August in Japan. $f_{\mathrm{VPD}}$ shows the response of stomatal conductance to vapor pressure deficit, scaled from 0 to 1 .

Tab. 4 - Correlation between AOT40 and $\mathrm{AF}_{\mathrm{st}} \mathrm{O}$ (accumulative stomatal ozone uptake) for each tree species in Japan. The correlation coefficient was calculated for each area including more than 5 grids. $(*)$ and $(* *)$ denotes the significance at $5 \%$ and $1 \%$ level, respectively. (NS) indicates no significant correlation.

\begin{tabular}{lccc}
\hline \multicolumn{1}{c}{ Region } & Quercus serrata & Fagus crenata & Betula ermanii \\
\hline All regions & $0.33^{* *}$ & $0.89^{* *}$ & $0.91^{* *}$ \\
Hokkaido - Central-eastern Japan & $0.53^{* *}$ & $0.93^{* *}$ & $0.93^{* *}$ \\
$\left(34^{\circ}-44^{\circ} \mathrm{N} 136^{\circ}-145^{\circ} \mathrm{E}\right)$ & & & - \\
Central Japan - Western Japan & $-0.06^{\mathrm{NS}}$ & $0.34^{*}$ & - \\
$\left(31^{\circ}-36^{\circ} \mathrm{N} 130^{\circ}-136^{\circ} \mathrm{E}\right)$ & & & \\
\hline
\end{tabular}

Tab. 5 - Correlation between $\mathrm{f}_{\mathrm{VPD}}$ (response of stomatal conductance to vapor pressure deficit) in summer and $\mathrm{AF}_{\mathrm{st}} \mathrm{O}$ (accumulative stomatal ozone uptake) for Quercus serrata in Japan. The correlation coefficient was calculated for each area including more than 5 grids. $\left(^{*}\right)$ and $(* *)$ denotes the significance at $5 \%$ and $1 \%$ level, respectively. (NS) indicates no significant correlation.

\begin{tabular}{lc}
\hline \multicolumn{1}{c}{ Region } & Value \\
\hline All regions & $0.43^{* *}$ \\
Hokkaido - Central-eastern Japan & $0.38^{* *}$ \\
$\left(34^{\circ}-44^{\circ} \mathrm{N} 136^{\circ}-145^{\circ} \mathrm{E}\right)$ & \\
Central Japan - Western Japan & $0.9^{* *}$ \\
$\left(31^{\circ}-36^{\circ} \mathrm{N} 130^{\circ}-136^{\circ} \mathrm{E}\right)$ & \\
\hline
\end{tabular}

the warmer part of Japan, the correlation between AOT40 and $\mathrm{AF}_{\mathrm{st}} \mathrm{O}$ decreased for Fagus crenata $(\mathrm{r}=0.37)$

\section{Discussion}

The purpose of this study was to compare the spatial map of the $\mathrm{AF}_{\mathrm{st}} \mathrm{O}$ and AOT40 values for deciduous forest trees in Japan. Emberson et al. (2000) and Simpson et al. (2007) similarly compared the spatial distribution of the stomatal ozone uptake and AOT40 values in Europe. The AOT40 value was relatively high in southern Europe compared to northern Europe. The spatial gradient of the AOT40 values was remarkable from south to north, but the spatial gradient of the stomatal ozone uptake was much less. Stomatal ozone uptake was limited due to drought stress during the summer in Mediterranean regions where ozone concentrations were high (Paoletti 2006).

In this study, $\mathrm{AF}_{\mathrm{st}} \mathrm{O}$ showed similarly much less regional differences than AOT40. However, there is a difference of the result compared to Europe. In Europe, the exposure-based critical level for forest species is suggested. Values of the critical levels are defined as $5 \mathrm{ppm} \cdot \mathrm{h}$ of AOT40. AOT40 values exceeding the European critical levels were shown in $89 \%$ of Japan. In Japan, Kohno et al. (2005) suggested that 15-30 $\mathrm{ppm} \cdot \mathrm{h}$ AOT40 for moderately sensitive spe- cies (e.g., Quercus serrata) from April to September as critical level for forest species. AOT40 values exceeding $30 \mathrm{ppm} \cdot \mathrm{h}$ were shown in $21 \%$ of Japan. Some regions where the AOT40 values reached $30 \mathrm{ppm} \cdot \mathrm{h}$ corresponded to cool and humid climate such as central-eastern Japan. Averaged stomatal ozone uptake was estimated to be higher than $40 \mathrm{mmol} \mathrm{m}^{-2}$ for the three species in central-eastern Japan (Tab. 3). In contrast, stomatal ozone uptake for Quercus serrata did not show any difference between eastern and central Japan, although AOT40 in central Japan was twice that in eastern Japan. Emberson et al. (2000) showed that VPD played a major role in limiting the stomatal ozone uptake. Also in this study, VPD is a limiting factor of the stomatal ozone uptake especially in warmer part of Japan (Tab. 5). For this reason, this region showed a discrepancy between the $\mathrm{AF}_{\mathrm{st}} \mathrm{O}$ values of Quercus serrata and AOT40. These results suggest that not only ozone concentration but also stomatal closure induced by VPD affected the $\mathrm{AF}_{\mathrm{st}} \mathrm{O}$ in the warmer part of Japan.

The results of correlation analysis for Fagus crenata and Betula ermanii suggested that $\mathrm{AF}_{\mathrm{st}} \mathrm{O}$ and $\mathrm{AOT} 40$ values are similar for ozone risk assessment in humid and cool climate region, because the correlation between AOT40 and $\mathrm{AF}_{\mathrm{st}} \mathrm{O}$ was very high (Tab. 4), i.e., humid and cool climate was favorable for stomatal opening. However, in the warmer part of Japan, the correlation between AOT40 and $\mathrm{AF}_{\mathrm{st}} \mathrm{O}$ decreased for Fagus crenata $(\mathrm{r}=0.37)$, because VPD induced a stomatal closure.

In warmer part of Japan, we also could find the difference of spatial pattern of the $\mathrm{AF}_{\mathrm{st}} \mathrm{O}$ values between Fagus crenata and Quercus serrata (Fig. 4). Stomatal conductance for Fagus crenata was less sensitive to high VPD ( $>2 \mathrm{kPa})$ than that for Quercus serrata (Tab. 1; Fig. 2). Therefore, the result is due to the species-specific characteristics of the stomatal conductance parameters. The assessment approach using AOT40 does not consider the difference of species-specific stomatal response to the climate factors. The result of this study illustrated the limitations of performing ozone risk assessment using AOT40 in Japan.

In this study, $f_{\text {SMD }}$ could not be applied in the model because of insufficient published data about soil moisture deficit. However, Sirisampan et al. (2003) reported that the soil water content had no effect on the stomatal conductance of six tree species in central Japan. However, soil water deficit may be a limiting factor in estimating $\mathrm{AF}_{\mathrm{st}} \mathrm{O}$ even for short periods during a growing season. The parameter of $f_{\mathrm{SMD}}$ would bring about a further refinement of the calculations for Japan. In addition, we assumed that plants absorbed ozone continuously when climate condition was favorable for stomatal ope- 
ning. However, when leaves experience a longer period of ozone exposure, stomatal response would be changed (Paoletti \& Grulke 2005). Pleijel et al. (2002) and Danielsson et al. (2003) reported that ozone exposure over a long time caused a decline in $g_{\max }$ for crops in their modelling studies. This effect has not included in the model of this study yet. Long-term ozone exposure would also be limiting factor of stomatal ozone uptake. Including the effects of ozone on stomatal conductance would be expected to improve the ozone uptake modelling for deciduous forests in Japan.

\section{Conclusions}

The maps between $\mathrm{AF}_{\mathrm{st}} \mathrm{O}$ and AOT40 for dominant temperate deciduous tree species in Japan were compared. Estimations of stomatal ozone uptake were accomplished using estimated ozone concentration and climate data, and vegetation data. As a result, stomatal closure induced by vapour pressure deficit affected the $\mathrm{AF}_{\mathrm{st}} \mathrm{O}$ values in warmer parts of Japan.

Therefore, the areas with the highest AOT40 did not correspond to the areas with the highest $\mathrm{AF}_{\mathrm{st}} \mathrm{O}$, suggesting that the use of AOT40 for protecting Japanese forests may be misleading.

Stomatal ozone uptake was suggested for assessing ozone damage more than three decades ago in Japan (Omasa et al. 1979). Many studies (e.g., Paoletti \& Manning 2007) suggested that the stomatal flux-based approach is scientifically-sound and would be a useful tool for ozone risk assessment. This paper is a contribution to develop the stomatal flux-based approach in Japan. Future work should validate and improve our model with field measurements. Parameterizations for more species would also contribute further developments because ozone sensitivity of plants and stomatal response to environmental condition are species-specific (e.g., Omasa et al. 2000).

\section{Acknowledgements}

This work was supported by JSPS Fellowships for Young Scientists and was partly supported by the Global Environment Research Fund (C-062) of the Ministry of the Environment, Japan.

\section{References}

Aoki Y, Hashimoto R (1995). Leaf phenology of woody plant species in a cool-temperate secondary forest of Quercus serrata. Bulletin of Iwate University Forests 26: 29-41 (in Japanese).

Danielsson H, Karlsson GP, Karlsson PE, Pleijel $\mathrm{H}$ (2003). Ozone uptake modeling and flux-response relationship - an assessment of ozone-induced yield loss in spring wheat. Atmospheric Environment 37: 475-485. - doi: 10.1016/S1352 2310(02)00924-X

Emberson LD, Ashmore MR, Cambridge HM,
Simpson D, Tuovinen JP (2000). Modelling stomatal ozone flux across Europe. Environmental Pollutition 109: 403-414. - doi: 10.1016/S02697491(00)00043-9

Emberson LD, Buker P, Ashmore MR (2007). Assessing the risk caused by ground level ozone to European forest trees: a case study in pine, beech and oak across different climate regions. Environmental Pollution 147: 454-466. - doi: 10.1016/j.envpol.2006.10.026

Endo S (1940). A Pleistocene flora from Siobara. Japan. Science Reports of the Tohoku Imperial Univesity $21: 47-\mathrm{A} 24$.

Fujimoto S (2008). Estimating the impact of the remal change on broad-leaved tree leaf phenology in the warm temperate zone. Japanese Journal of Conservation Ecology 13: 75-87. (in Japanese with English summary).

Grell GA, Peckham SE, Schmitz R, McKeen SA, Frost G, Skamarock WC, Eder B (2005). Fully coupled online chemistry within the WRF model. Atmospheric Environment 39: 6957-6975. - doi: 10.1016/j.atmosenv.2005.04.027

Iio A, Fukasawa H, Nose Y, Kakubari Y (2004). Stomatal closure induced by high vapor pressure deficit limited midday photosynthesis at the canopy top of Fagus crenata Blume on Naeba Mountain in Japan. Trees 18: 510-517. - doi: 10.1007/s00468-004-0327-x

Izuta T, Matsumura H, Kohno Y, Shimuzu H (2001). Experimental studies on the effects of ozone on forest tree species. Journal of Japan Society for Atmospheric Environment 36: 60-77. (in Japanese with English summary). - doi: 10.1103/PhysRevA.41.4367

Jarvis PG (1976). Interpretation of variations in leaf water potential and stomatal conductance found in canopies in field. Philosophical Transactions of the Royal Society of London series B 273: 593-610. - doi: 10.1098/rstb.1976.0035

Karlsson PE, Braun S, Broadmeadow M, Elvira S, Emberson L, Gimeno BS, Le Thiec D, Novak K, Oksanen E, Schaub M, Uddling J, Wilkinson M (2007). Risk assessments for forest trees: the performance of the ozone flux versus the AOT concepts. Environmental Pollution 146: 608-616. doi: 10.1016/j.envpol.2006.06.012

Kato J, Hayashi I (2008). Phenological studies of deciduous trees in the cool temperate region of Japan. Journal of Ecology and Field Biology 31: 193-200. - doi: 10.5141/JEFB.2008.31.3.193

Kohno Y, Matsumura H, Ishii T, Izuta T (2005). Establishing critical levels of air pollutants for protecting East Asian vegetation - a challenge. In: "Plant responses to air pollution and global change" (Omasa K, Nouchi I, De Kok LJ eds). Springer, Tokyo, Japan, pp. 243-250.

Maruyama K, Honda M (1993). Stomatal responses in Fagus crenata, Quercus crispula and $Q$. serrata seedlings. Research Bulletin of the Niigata University Forests 26: 75-88. (in Japanese with English summary)

Muraoka H, Koizumi H (2005). Photosynthetic and structural characteristics of canopy and shrub trees in a cool-temperate deciduous broadleaved forest: implication to the ecosystem car- bon gain. Agricultural and Forest Meteorology 134: 39-59. - doi: 10.1016/j.agrformet.2005.08. 013

Nies (1980). Studies on the effects of air pollutants on plants and mechanisms of phytoxicity. Research Report from the National Institute of Environmental Studies, Japan. - doi: 10.2466/ PMS.85.5.155-160

Nies (1984). Studies on effects of air pollutant mixtures on plants (Parts 1 \& 2). Research Report from the National Institute of Environmental Studies, Japan. - doi: 10.1097/00001648199503000-00033

Naja M, Akimoto H (2004). Contribution of regional pollution and long-range transport to the Asia-Pacific region: Analysis of long-term ozonesonde data over Japan. Journal of Geophysical Research 109: D21306. - doi: 10.1029/ 2004JD004687

Nakai Y, Kitamura K, Suzuki S, Abe S (2003). Year-long carbon dioxide exchange above a broadleaf deciduous forest in Sapporo. Tellus 55B: 305-312. - doi: 10.1034/j.1600-0889.2003. 01413.x

Nakashizuka T, Iida S (1995). Composition, dynamics and disturbance regime of temperate deciduous forests in Monsoon Asia. Vegetatio 121: 23-30. - doi: 10.1007/BF00044669

Ohara T, Sakata T (2003). Long-term variation of photochemical oxidants over Japan. Journal of Japan Society for Atmospheric Environment 38: 47-54. (in Japanese with English summary).

Omasa K, Abo F, Natori T, Totsuka T (1979). Studies of air pollutant sorption by plants. II Sorption under fumigation with $\mathrm{NO}_{2}, \mathrm{O}_{3}$ or $\mathrm{NO}_{2}+\mathrm{O}_{3}$. Journal of Agricultural Meteorology 35: 77-83. (in Japanese with English summary). Omasa K, Tobe K, Hosomi M, Yoshida M, Kobayashi M (2000). Experimental studies on $O_{3}$ sorption mechanism of green area - analysis of $\mathrm{O}_{3}$ sorption rates of plants and soils. Environmental Science 13: 33-42. (in Japanese with English summary)

Omasa K, Tobe K, Kondo T (2002). Absorption of organic and inorganic air pollutants by plants. In: "Air pollution and plant biotechnology" (Omasa K, Saji H, Youssefian N, Kondo N eds). Springer, Tokyo, Japan, pp. 155-178.

Ozaki Y, Terada K, Yamashita T (2000). Leaf and shoot phenology of trees in a deciduous broadleaved secondary forest in the Sambe Forest, Shimane University. Bulletin of faculty of life and environmental science, Shimane University 5: 67-71. (in Japanese with English summary).

Paoletti E (2006). Impact of ozone on Mediterranean forests: a review. Environmental Pollution 144: 463-474. - doi: 10.1016/j.envpol.2005. 12.051

Paoletti E, Grulke N (2005). Does living in elevated $\mathrm{CO}_{2}$ ameliorate tree response to ozone? $\mathrm{A}$ review on stomatal response. Environmental Pollution 137: 483-493. - doi: 10.1016/j.envpol. 2005.01.035

Paoletti E, Manning WJ (2007). Toward a biologically significant and usable standard for ozone that will also protect plants. Environmental Pol- 
lution 150: 85-95. - doi: 10.1016/j.envpol.2007. 06.037

Pleijel H, Danielsson H, Vandermeiren K, Blum C, Colls J, Ojanpera K (2002). Stomatal conductance and ozone exposure in relation to potato tuber yield: - results from the European CHIP programme. European Journal of Agronomy 17: 303-317. - doi: 10.1016/S1161-0301 (02)00068-0

Simpson D, Ashmore MR, Emberson L, Tuovinen JP (2007). A comparison of two different approaches for mapping potential ozone damage to vegetation. a model study. Environmental Pollution 146: 715-725. - doi: 10.1016/j.envpol.2006. 04.013

Sirisampan S, Hiyama T, Takahashi A, Hashimoto T, Fukushima Y (2003). Diurnal and seasonal variations of stomatal conductance in a secondary temperate forest. Journal of Japan Society of Hydrological \& Water Resources 16: 113-130. (in Japanese with English summary). doi: 10.3178/jjshwr.16.113

Sudo K, Takahashi M, Kurokawa J, Akimoto H (2002). CHASER: a global chemical model of the troposphere. 1. Model description. Journal of Geophysical Research - Atmospheres 107 (D17): 4339. - doi: 10.1029/2001JD001113

Takigawa M, Niwano M, Akimoto H, Takahashi M (2007). Development of a one-way nested global-regional air quality forecasting model. Sola 3: 81-84. - doi: 10.2151/sola.2007-021

Tanaka K, Kosugi Y, Ohte N, Kobashi S, Nakamura A (1998). Model of $\mathrm{CO}_{2}$ flux between a plant community and atmosphere, and simulation of $\mathrm{CO}_{2}$ flux over a planted forest. Japanese Journal of Ecology 48: 265-286. (in Japanese with English summary).

UNECE (2004). Mapping critical levels for vegetation. Chapter 3: Manual on methodologies and criteria for modelling and mapping critical loads and levels and air pollution effects, risks and trends. Umweltbundesamt, Berlin, Germany.

Watanabe M, Matsuo N, Yamaguchi M, Matsumura H, Kohno Y, Izuta T (2010). Risk assessment of ozone impact on the carbon absorption of Japanese representative conifers. European Journal of Forest Research 129: 421-430. - doi: 10.1007/s10342-009-0316-0

Yamazaki T, Kato K, Kuwada T, Nakai T, Park H, Ohta T (2006). Land surface model simulation on CREST forest sites using measured leaf-scale physiological parameters. In: "International workshop on $\mathrm{H}_{2} \mathrm{O}$ and $\mathrm{CO}_{2}$ exchanges in Siberia”. Amsterdam, The Netherlands, pp. 81-84. 